Article

\title{
Taxonomic analysis of the level of private equity/ venture capital market development in Europe
}

\author{
Elżbieta Grzegorczyk ${ }^{1}$ \\ 1 University of Lodz, Faculty of Economics and Sociology, Institute of Finance, Department of Finance and \\ Accounting of SMEs, Poland, elzbieta.grzegorczyk@uni.lodz.pl, Tel.: +48-660-729-794
}

\begin{abstract}
Determining the level of PE/VC market development and the way it operates is extremely difficult. Despite countless reports and analyses concerning the PE/VC market, there is a lack of study on that sector based on a synthetic index. The usage of taxonomic methods in the PE/VC market analysis may be extremely useful in its proper characterizing. An in-depth study allows the identification of weaknesses and strengths as well as opportunities and threats related to a specific stage of PE/VC market development in a given country, that gives the opportunity to determine public activities that could affect the acceleration of this market development in future. The main objective of the study was to conduct a taxonomic analysis of the level of PE/VC market development in Europe, in 2010-2015. It is worth mentioning that the term "level of development" does not refer only to the value of investment or its dynamics, but to a set of objectified features that create one synthetic indicator. The conducted analysis using the Hellwig method allowed to determine the ranking of European countries in terms of the level of PE/VC market development, which reveal some significant differences in the functioning of the this market within Europe. Further detailed analysis of the designated groups of countries made it possible to determine the characteristics of such clusters. The construction of the level of private equity/venture capital market development ranking over the years enabled defining the current status and indicating the direction of possible changes.
\end{abstract}

Keywords: Hellwig method, taxonomy, venture capital.

JEL Classification: G1, O16, O52

\section{Introduction}

Nowadays, PE/VC market is seen as the factor stabilizing the financial and capital market, especially during the economic crisis. European Union institutions as well appreciate the role of these investments, especially VC, which is proved by the multiple use of PE/VC entities as the intermediary of capital in the EU financing programs implemented. The analysis of the current state and level of development of this market and its reaction to market turbulences in recent years, in relation to the situation of other European countries, is therefore important for understanding the mechanisms of its existence, in order to identify areas of actions accelerating its development.

Despite considerable interest in the subject of venture capital, there is lack in the literature of the analysis of the level of PE/VC market development based on a synthetic index. Countless reports and analyses concerning the PE/VC market were created, containing a lot of information presented from different perspectives, however, they do not give the possibility to make comparisons on a global basis. The construction of the level of private equity/venture capital market development ranking over the years, such as for example - already existing over 10 years - Innovation Index (European Innovation Scoreboard), would enable defining the current status, indicating the direction of possible changes and verifying the validity of the implemented strategies. 
The main objective of the study was to conduct a taxonomic analysis of the level of PE/VC market development in Europe, in 2010-2015, when the comparable data were available. The analysis allowed to determine the ranking of European countries from the perspective of PE/VC market. It is worth mentioning that the term "level of development" does not refer only to the value of investment or its dynamics, but to a set of objectified features that create one indicator of the level of PE/VC market development. Thanks to the study and the analysis of other countries experience, weaknesses and strengths, as well as, opportunities and threats arising from a particular stage of PE/VC market development of the can be identified. It gives the opportunity to plan certain activities that could affect the acceleration of the development of this sector, and indirectly the economy of a particular country.

In the study there were used data collected and processed by research agencies and public institutions such as Invest Europe (previously EVCA), Eurostat, State Statistics Service of Ukraine (due to the limited data in Eurostat for Ukraine, information were obtained directly from the Department of International Cooperation and Integration European Statistical Office of Ukraine and data published by this Office).

\section{Methodology}

The PE/VC market is a complex object, thus the level of its development is determined by many characteristics. Such as in the case of technical progress assessment, social and economic development valuation, living conditions or technical infrastructure evaluation, the assessment of the level of PE/VC market development in particular countries generates a significant problem. The level of market similarity in two countries measured by one indicator may be high, however, due to another feature, can be low. Therefore, it is worth using the methods of taxonomic comparative analysis.

A taxonomic analysis is a scientific discipline that allows the study of complex objects, which variation is simultaneously influenced by many factors. Professor Zdzislaw Hellwig defined it as "methods and techniques for comparing multi-feature objects" (Hellwig 1981). Taxonomic analysis covers research activities such as assessing the similarity of individual units, their sequence and classification (Nowak 1997). These methods are used in economic studies to determine the order of objects difficult to be classified on the basis of only one feature, such as the classification of countries due to the level of economic development of enterprises or due to their financial condition (Bąk 2016). They can be determined only by measuring the values of aggregate variables comprising of individual observations (Bąk 2013).

In the literature there are presented many classifications of a multi-parameter methods. They differ by procedure, area of application, level of calculation effort, formalization degree or duration. Such a large diversity of taxonomic methods results from the complexity of the multi-feature classification as well as from the fact there are many ways to create groups of units with similar characteristics. In this regard, the choice of appropriate classification method is not simple. Professor Z. Hellweg (Hellwig 1968) was the first who founded a synthetic development measure method. Hellwig's method synthesizes information from series of diagnostic measures and assigns to the analyzed phenomenon one aggregate feature (Krakowiak-Bal 2005) presented by one numerical value, which facilitates all comparisons between European countries. It is a method that was used to analyze the level of PE/VC market development in European countries.

\subsection{Hellwig method scheme}

The Hellwig method is a linear ordering method, which is based on projecting on a straight line individual points located in a multidimensional space. The analyzed objects are put in order based on the development index formula, which is a synthetic measure, combining information from a series of variables into one aggregate indicator (Grabiński 1992).

To analyse the level of PE/VC market development in European countries using the taxonomic cluster analysis, it is necessary to identify the factors describing the development of this market. It allows to establish the hierarchy of objects by ordering them from the highest to the lowest and thus distinguish groups of objects similar to each other by achieving factors that are considered to be 
Where:

$100 x_{i j}$-value of the $j$ diagnostic variable for the $i$ object;

$101 \quad i=(1,2 \ldots, \mathrm{m}) ; m-$ number of objects;

$102 j=(1,2 \ldots, \mathrm{k}) ; k-$ number of diagnostic variable.

Afterwards, there should be determined the nature of the diagnostic variable. If higher values of a given variable allow to qualify the object as better within the general criterion, this is called a stimulant. On the other hand, when the higher values of the property cause a worse assessment of the object, then it is the destimulant (Depta 2005). In taxonomic analysis, it is also important to unify the level of variability of features in order to ensure their comparability. To bring the characteristics to be comparable, it is necessary to standardized them based on the formula (2) below:

$$
X=\left[\begin{array}{c}
X_{1} \\
X_{2} \\
\ldots \\
X_{m}
\end{array}\right]=\left[\begin{array}{cccc}
X_{11} & x_{12} & \ldots & x_{1 k} \\
X_{21} & x_{22} & \ldots & x_{2 k} \\
\ldots & \ldots & \ldots & \ldots \\
X_{m 1} & X_{m 2} & \ldots & x_{m k}
\end{array}\right]
$$

110 where:

$111 x_{i j}$ - empirical value of $j$ diagnostic variable for $i$ object,

$112 \bar{x}_{j}-$ arithmetic average of diagnostic variable $x_{j}$,

$113 S_{x j}$ - standard deviation from diagnostic variable $x_{j}$.

114 As a result of standardization, there is obtained a standard synthetic variable, called development 115 model $\boldsymbol{P}_{0 j}$ (Hellwig 1968) presented in the formula (3):

where:

$$
P_{0 j}=\left[z_{01}, z_{02}, \ldots, z_{0 k}\right]
$$

$119 z_{0 j}=\max \left(z_{i j}\right)$ for variables that are stimulants,

$120 \quad z_{0 j}=\min \left(z_{i j}\right)$ for variables that are destimulants.

121 This formula can be defined by the best observed value or on the basis of expert knowledge by 122 adopting arbitrary values of the standard.

For the destimulant, you can transpose variables into stimulants using below formula (4):

$$
2 \bar{x}-x_{i j}
$$

In the further stage of the research, for each analysed object, the distance from development model $P_{0 j}$ should be determined. The Euclidean distance formula (Shraddha, Suchita, 2011) (or its square) is most commonly used (5):

$$
d_{i 0}=\sqrt{\sum_{j=1}^{k}\left(z_{i j}-z_{0 j}\right)^{2}}, \text { for } i=(1,2 \ldots, \mathrm{m}) \text { and } j=(1,2 \ldots, \mathrm{k})
$$

130 where:

$131 \mathrm{Z}_{\mathrm{ij}}$ - normalized value of $j$ variable for $i$ object,

$132 \quad z_{0 j}-$ normalized development index model value for $j$ variable. 
133 Then a relative taxonomic development index measure for individual objects is calculated in order to

134

135

136

137

138

139 normalize the coefficient dio:

$$
z_{i}=1-\frac{d_{i 0}}{d_{0}}
$$

where:

$d_{0}=\bar{d}_{0}+2 S_{0}$,

$\bar{d}_{0}=\frac{1}{m} \sum_{i=1}^{m} d_{i 0}$

$S_{0}=\sqrt{\frac{1}{m} \sum_{i=1}^{m}\left(d_{i 0}-\bar{d}_{0}\right)^{2}}$,

$\bar{d}_{0}$ - the arithmetic average of the designated distances from the development model, $S_{0}$-standard deviation from the determined distances from the development model.

The higher the value of the distance, the more object is closer to the pattern and the better is its' situation. A result close to zero indicates a very unfavourable situation of the analysed object. On the basis of the value of taxonomic development measure, it is possible to set in order the objects due to the level of PE/VC market development.

On the basis of the calculated synthetic measure, a linear arrangement of objects is made. The determination of Hellwig's synthetic development index can be additionally supplemented by division of units into clusters (Grabiński, Wydymus, Zeliaś 1989), using the arithmetic average and standard deviation from the relative value of the development measure. The objects can be divided into four typological groups: from very good to insufficient. It should be noted that the proposed assessments are relative, i.e. only within countries taken into account in the analysis and due to available diagnostic variables (Warzecha 2013).

\subsection{Identifications of factors for analysis}

The concept of "level of development" is characterized by the structure and therefore it should be verified to what extent certain results for the factors considered to be relevant in given case, have been achieved (Grajewska 2013). Proper market specification is extremely important as it allows a better understanding of the mechanisms affecting its development. The particular features were selected on the basis of substantive and statistical prerequisites. The selection of indicators for the study was made taking into account different spheres of the PE/VC market, so that the final result allowed to determine which of the European countries belong to the group with very high, high, moderate and low level of development of the analysed market.

Due to the fact that the aim of the study was to determine the level of PE/VC market development, by key factors there were considered to be those that determine its shape, form and condition. Thus, the study contains information that characterizes the market, i.e. its size, dynamics of development, industry structure, investment structure due to stage of enterprises development, etc. Because external factors, which determine the country's economic, technological and social level, also have an (indirect) impact on the PE/VC market, they could not be completely neglected. However, it is important not to introduce too many external factors that could "flatten" the results of the research and bring them to the general economic dimension. External factors affecting the PE/VC market in European countries have been identified by using own econometric method and earlier analyses and researches conducted by, among others, Artur Zimny (Zimny 2013).

The study covered a period of six years, until 2015, due to the fact that the most recent statistical yearbooks published by Invest Europe, have a new structure of calculations and only part of data for 
previous years has been adapted to the new criteria. Joining most recent data to the analysis, where part of factors were calculated on slightly different basis, would deprive the possibility of making comparisons with previous years.

Considering the above findings, for the study there were initially proposed 37 indicators determining the level of PE/VC market development (creating a potential set of features) divided into four following segments:

1. General features of PE/VC market;

2. PE/VC market environment;

3. Industry structure of PE/VC market (Sectoral Classification 2016);

4. Structure of PE/VC investments due to the company development phases.

The statistical data were gathered based on EVCA (Invest Europe) Yearbooks (Yearbook 2016) and reports with dataset on all European countries (Yearbook Dataset 2015), as well as, Eurostat database such as patent applications to the European patent office (Patent applications 2016), and human resources in science and technology - HRST (Human resources 1995 \& 2016). In order to solve the problem of variable weighing, there was made the assumption on the same importance of each analysed feature. In the next stage of the study, the character of each traits was determined, distinguishing among them stimulants (a diagnostic variable where a higher value means better situation of the object) and destimulants (where a higher value means worse situation of the object), taking into account the substantive meaning of individual features. They were marked with the letters [S] and [D] respectively. It was assumed, that in some cases the higher value means deterioration (weakening) of the level of PE/VC market development. Thus destimulants were:

- share of PE/VC investments financed by public entities (the higher the level of PE/VC market development makes it more independent from state funds);

- $\quad$ share of domestic PE/VC investments of total PE/VC investment (the developed PE/VC market should attract foreign capital.) The market, which is financed only by domestic capitals, is a closed market, which may affect its slower growth);

- $\quad$ share of PE/VC investment in agriculture (this sector is relatively low innovative and not technology driven in comparison with others).

The differences and correlations between individual variables were verified in the study and diagnostic variables were selected, reducing the original set of features by the following indicators: $\mathrm{X} 3, \mathrm{X} 4, \mathrm{X} 6, \mathrm{X} 8, \mathrm{X} 9, \mathrm{X} 13, \mathrm{X} 14$ (see table 1). The remaining variables were used in the Hellweg synthetic index assessment of the level of PE/VC market development in Europe. From among mentioned indicators, there were finally included 30 variables in the study. Table 1 below presents a list of variables, with an indication of which were included in the study.

Table 1. Variables defined for the Hellwig method after initial verification, with the specification

\begin{tabular}{|c|c|c|c|}
\hline Group & $\begin{array}{l}\text { In the } \\
\text { analysis }\end{array}$ & Designation and name of the feature & $\begin{array}{l}\text { Stimulant/ } \\
\text { Destimulant }\end{array}$ \\
\hline 1 & Yes & $\begin{array}{l}\mathrm{X} 1 \text { - The value of PE/VC investment in Europe }{ }^{\text {a }} \text { (investment by location of PE } \\
\text { offices investing in European companies) in relation to GDP per capita }\end{array}$ & S \\
\hline 1 & Yes & $\mathrm{X} 2$ - The change of PE/VC investment value compared to the previous year & $S$ \\
\hline 1 & No & $\mathrm{X} 3$ - The total number of PE/VC companies / funds & - \\
\hline 1 & No & $\mathrm{X} 4$ - The total number of enterprises receiving $\mathrm{PE} / \mathrm{VC}$ funding & - \\
\hline 1 & Yes & X5 - The share of PE/VC investments financed by public entities & $\mathrm{D}$ \\
\hline 1 & No & X6 - The share of PE/VC investments financed by private and mixed entities & - \\
\hline 1 & Yes & X7 - The share of PE/VC investments made by domestic entities & $\mathrm{D}$ \\
\hline 1 & No & $\begin{array}{l}\text { X8 - The share of PE / VC investments made by domestic entities from outside } \\
\text { EU }\end{array}$ & - \\
\hline
\end{tabular}




\begin{tabular}{|c|c|c|c|}
\hline 1 & No & X9 - The GDP per capita & - \\
\hline 2 & Yes & $\mathrm{X} 10$ - The share of PE/VC investments in GDP & $\mathrm{S}$ \\
\hline 2 & Yes & $\begin{array}{l}\text { X11 - The total European patent applications to the European Patent Office } \\
(\mathrm{EPO})^{\mathrm{b}} \text { (regardless of whether they are granted or not) in relation to GDP per } \\
\text { capita (Patent applications 2016) }\end{array}$ & $\mathrm{S}$ \\
\hline 2 & Yes & $\begin{array}{l}\text { X12 - The human resources in science and technology (HRST) as a share of the } \\
\text { active population in the age group 25-64 (Human resources } 1995 \& 2016)\end{array}$ & $\mathrm{S}$ \\
\hline 2 & No & X13 - The corporate income tax rate CIT & - \\
\hline 2 & No & X14 - The interest rate on 10-year state securities & - \\
\hline 3 & Yes & $\mathrm{X} 15$ - The share of PE/VC investments in agriculture & $\mathrm{D}$ \\
\hline 3 & Yes & $\mathrm{X} 16$ - The share of PE/VC investments in business and industrial products & $\mathrm{S}$ \\
\hline 3 & Yes & $\mathrm{X} 17$ - The share of PE/VC investments in business and industrial services & S \\
\hline 3 & Yes & $\mathrm{X} 18$ - The share of PE/VC investments in chemicals and materials & $\mathrm{S}$ \\
\hline 3 & Yes & $\mathrm{X} 19$ - The share of PE/VC investments in communications & $S$ \\
\hline 3 & Yes & $\mathrm{X} 20$ - The share of PE/VC investments in computer \& consumer electronics & S \\
\hline 3 & Yes & $\mathrm{X} 21$ - The share of PE/VC investments in construction & $S$ \\
\hline 3 & Yes & $\mathrm{X} 22$ - The share of PE/VC investments in consumer goods \& retail & $S$ \\
\hline 3 & Yes & $\mathrm{X} 23$ - The share of PE/VC investments in consumer services & S \\
\hline 3 & Yes & $\mathrm{X} 24$ - The share of PE/VC investments in energy \& environment & S \\
\hline 3 & Yes & $\mathrm{X} 25$ - The share of PE/VC investments in financial services & $S$ \\
\hline 3 & Yes & X26 - The share of PE/VC investments in life sciences ${ }^{c}$ & $\mathrm{~S}$ \\
\hline 3 & Yes & $\mathrm{X} 27$ - The share of PE/VC investments in real estate & $S$ \\
\hline 3 & Yes & $\mathrm{X} 28$ - The share of PE/VC investments in transportation & $\mathrm{S}$ \\
\hline 3 & Yes & $\mathrm{X} 29$ - The share of PE/VC investments in unclassified sectors & $S$ \\
\hline 3 & Yes & X30 - The share of PE/VC investments in high-tech (total) & S \\
\hline 4 & Yes & X31 - The share of PE/VC investments in seed phase [seed capital] & S \\
\hline 4 & Yes & X32 - The share of PE/VC investments in start-up phase [start-up capital] & $\mathrm{S}$ \\
\hline 4 & Yes & $\begin{array}{l}\text { X33 - The share of PE/VC investments in later venture phase [later stage } \\
\text { venture] }\end{array}$ & $\mathrm{S}$ \\
\hline 4 & Yes & X34 - The share of PE/VC investments in growth phase [growth capital] & S \\
\hline 4 & Yes & X35 - The share of PE/VC investments in rescue phase [rescue/ turnaround] & $\mathrm{S}$ \\
\hline 4 & Yes & $\begin{array}{l}\text { X36 - The share of PE/VC investments in replacement phase [replacement } \\
\text { capital] }\end{array}$ & $\mathrm{S}$ \\
\hline 4 & Yes & X37 - The share of PE/VC investments in buyout phase [buyout capital] & S \\
\hline
\end{tabular}

213 a The value of PE/VC investment taken from aggregate tables for European countries (not individual country 214 tables). Such a choice results from the fact that the data included in collective summaries are more comparable.

$215 \mathrm{~b}$ The total European patent applications refer to requests for protection of an invention directed either directly 216 to the European Patent Office or filed under the Patent Cooperation Treaty and designating the EPO (Euro-PCT), 217 regardless of whether they are granted or not. The data shows the total number of applications per country.

218 c life sciences - in the context of human health. This industry includes: medicine, pharmacy and healthcare.

The author is aware that the proposed indicators do not exhaust the multidimensional approach 222 infinitively. However, the features proposed and characterized were considered to be the most important from the point of view adopted in the study. In addition, the lack of uniformity of obtained 
224 data and the limited availability of some variables have reduced the number of factors that could 225 have been used in the proposed study.

\section{3. Results}

The aim of the study was to create one synthetic indicator that would contain information on many variables regarding the PE/VC market. The created index allowed to build the rank of European countries according to the level of PE/VC market development. The cluster analysis carried out for

230 the nine-year period (2010-2015) brought the results indicated in the following Table 2. To improve 231 the visualization, international two-element codes of countries were used. For the purpose of 232 marking groups of countries analyzed in the study, the following abbreviations were used: Bal 233 Baltic countries (Lithuania, Latvia, Estonia); CEE - Central and Eastern Europe: former Yugoslavia 234 and Slovakia (Croatia, Slovakia, Slovenia).

Table 2. The values of the Hellwig synthetic index measure of PE/C market development for European countries in 2010-2015

\begin{tabular}{lccccccccccccc}
\hline $\begin{array}{l}\text { Country } \\
\text { code }\end{array}$ & $\mathbf{2 0 1 0}$ & $\mathbf{2 0 1 1}$ & $\mathbf{2 0 1 2}$ & $\mathbf{2 0 1 3}$ & $\mathbf{2 0 1 4}$ & $\mathbf{2 0 1 5}$ & $\begin{array}{l}\text { Country } \\
\text { code }\end{array}$ & $\mathbf{2 0 1 0}$ & $\mathbf{2 0 1 1}$ & $\mathbf{2 0 1 2}$ & $\mathbf{2 0 1 3}$ & $\mathbf{2 0 1 4}$ & $\mathbf{2 0 1 5}$ \\
\hline AT & 0,075 & 0,086 & 0,096 & 0,115 & 0,099 & 0,105 & LU & 0,077 & 0,054 & 0,101 & 0,085 & 0,101 & 0,085 \\
Bal & 0,108 & 0,077 & 0,078 & 0,081 & 0,091 & 0,075 & NL & 0,122 & 0,083 & 0,147 & 0,115 & 0,102 & 0,102 \\
BE & 0,120 & 0,077 & 0,117 & 0,105 & 0,112 & 0,109 & NO & 0,077 & 0,069 & 0,11 & 0,042 & 0,086 & 0,083 \\
BG & 0,032 & 0,025 & 0,014 & 0,008 & 0,036 & 0,038 & CEE & 0,061 & 0,028 & 0,039 & 0,053 & 0,051 & 0,047 \\
CZ & 0,060 & 0,038 & 0,040 & 0,045 & 0,057 & 0,050 & PL & 0,044 & 0,039 & 0,085 & 0,069 & 0,05 & 0,054 \\
DE & 0,131 & 0,067 & 0,123 & 0,091 & 0,089 & 0,105 & PT & 0,057 & 0,063 & 0,096 & 0,112 & 0,086 & 0,117 \\
FI & 0,080 & 0,058 & 0,095 & 0,055 & 0,089 & 0,060 & RO & 0,028 & 0,047 & 0,033 & 0,062 & 0,037 & $-0,004$ \\
FR & 0,135 & 0,134 & 0,15 & 0,122 & 0,147 & 0,150 & ES & 0,092 & 0,059 & 0,107 & 0,071 & 0,062 & 0,105 \\
DE & 0,146 & 0,111 & 0,126 & 0,102 & 0,106 & 0,126 & SE & 0,107 & 0,056 & 0,111 & 0,077 & 0,071 & 0,117 \\
GR & 0,044 & 0,032 & $-0,02$ & $-0,013$ & $-0,020$ & 0,005 & CH & 0,09 & 0,056 & 0,107 & 0,113 & 0,118 & 0,115 \\
HU & 0,075 & 0,047 & 0,031 & 0,043 & 0,028 & 0,051 & UA & $-0,035$ & 0 & 0,057 & 0,022 & 0,015 & 0,048 \\
IE & 0,083 & 0,058 & 0,103 & 0,053 & 0,118 & 0,089 & UK & 0,15 & 0,124 & 0,169 & 0,119 & 0,129 & 0,156 \\
IT & 0,109 & 0,030 & 0,101 & 0,047 & 0,055 & 0,050 & & & & & & &
\end{tabular}

It is also worth to analyse the descriptive characteristics for synthetic variables being the result of the study, which are presented in the below Table 3. There were used:

- location measures (including: arithmetic average, median, quartiles 1 and 3),

- differentiation measures (among others: standard deviation, range),

- $\quad$ asymmetry measures (among others: asymmetry coefficient). A positive value of this coefficient indicates a right-sided asymmetry (the larger part of the population takes values above the average), while a negative one is left-sided (the larger part of the population takes values below the average).

Table 3. Descriptive characteristics of synthetic index measures describing the level of PE/VC market development in European countries in 2010-2015

\begin{tabular}{lcccccc}
\hline Measurement & $\mathbf{2 0 1 0}$ & $\mathbf{2 0 1 1}$ & $\mathbf{2 0 1 2}$ & $\mathbf{2 0 1 3}$ & $\mathbf{2 0 1 4}$ & $\mathbf{2 0 1 5}$ \\
\hline Average & 0,0828 & 0,0606 & 0,0886 & 0,0718 & 0,0767 & 0,0816 \\
\hline
\end{tabular}




\begin{tabular}{lrrrrrr}
\hline Quartile 1 & 0,0584 & 0,0384 & 0,0482 & 0,0456 & 0,0506 & 0,0502 \\
Median & 0,0805 & 0,0581 & 0,1008 & 0,0710 & 0,0862 & 0,0846 \\
Quartile 3 & 0,1148 & 0,0772 & 0,1139 & 0,1083 & 0,1042 & 0,1118 \\
Minimum & $-0,0351$ & $-0,0002$ & $-0,0198$ & $-0,0125$ & $-0,0199$ & $-0,0041$ \\
Maximum & 0,1501 & 0,1336 & 0,1691 & 0,1222 & 0,1470 & 0,1563 \\
Range & 0,1851 & 0,1338 & 0,1889 & 0,1347 & 0,1669 & 0,1603 \\
Standard deviation & 0,0414 & 0,0303 & 0,0443 & 0,0359 & 0,0383 & 0,0401 \\
Asymmetry coefficient & 0,0557 & 0,0829 & $-0,2746$ & 0,0209 & $-0,2493$ & $-0,0751$ \\
\hline
\end{tabular}

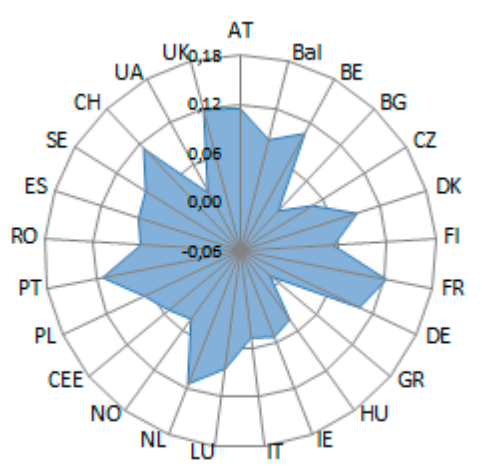

2013

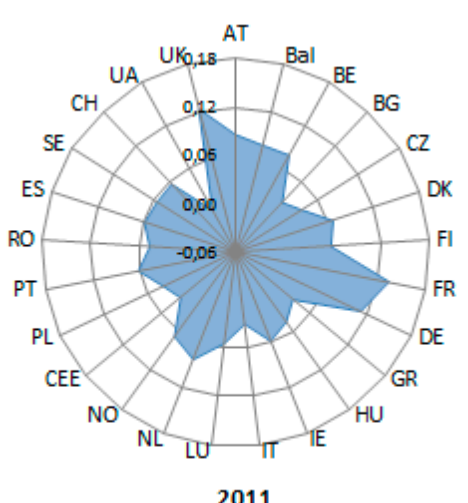

2011

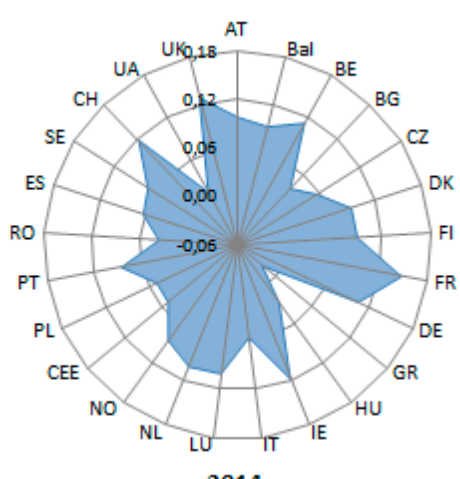

2014

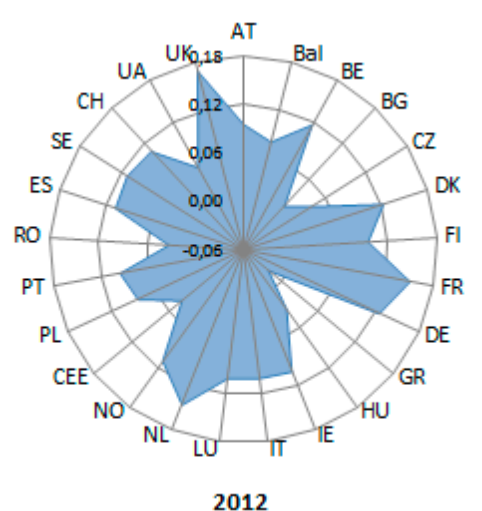

2012

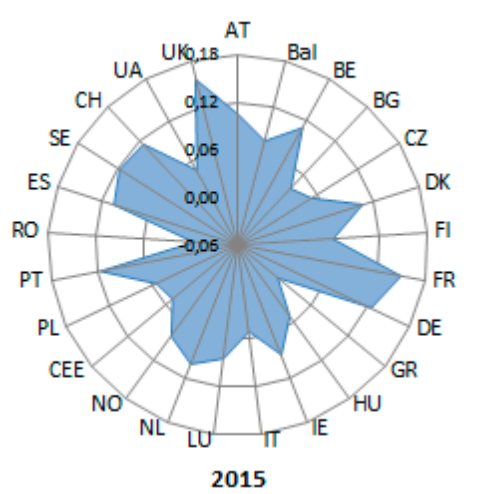

Figure 1. The distance of the synthetic index for particular European countries from the Hellwig development formula in 2010-2015 
These graphs can be described as linear, in which the axis " $x$ " is represented by the central point, and the values of individual objects are marked on separate axes "y". In the following radar charts on the $y$-axes there were marked the values of the synthetic measure of PE/VC market development in European countries in particular years, according to the results of Hellwig's analysis. According to the above radar charts, over the 6 analysed years, some countries, such as France, United Kingdom, Germany, Netherlands, were distinguished by the highest value of the measure, while Greece, Bulgaria, Ukraine and Romania by the lowest. Although some pattern can be observed in the case of the countries indicated, there were relatively significant changes in the level of PE/VC market development among other European countries. Therefore, more detailed analysis is necessary.

On the basis of the calculated synthetic index, European countries have therefore been ranked in a linear manner, according to the obtained measures, from countries with the best condition of the PE/VC market, to those in which the market is still underdeveloped. In addition, countries were grouped into four clusters separated by an arithmetic average and standard deviation for a relative development measure. This way, four categories of countries were selected, as presented in Table 4.

Table 4. The rules of grouping European countries based on the criteria used in Hellwig method

\begin{tabular}{|c|c|c|c|}
\hline Gr. & $\begin{array}{c}\text { Level PE/VC of } \\
\text { development }\end{array}$ & Boundary condition 1 & Boundary condition 2 \\
\hline G1 & Very high & Average + Standard deviation $<\mathbf{z i}_{\mathbf{i}}$ & $\mathbf{Z}_{\mathbf{i}}<1$ \\
\hline G2 & High & Average $<\mathbf{z i}$ & $\mathbf{Z i}<$ Average + Standard deviation \\
\hline G3 & Moderate & Average-Standard deviation $<\mathbf{z i}$ & $\mathbf{z}_{\mathbf{i}}<$ Average \\
\hline G4 & Low & $0<\mathbf{Z i}_{\mathbf{i}}$ & $\mathbf{Z}_{\mathbf{i}}<$ Average - Standard deviation \\
\hline
\end{tabular}

The results of the conducted ranking and assignment to the distinguished groups are presented in table 5. The typological grouping of countries based on the average and standard deviation provided groups of different size. It should be noted that the proposed assessments are relative, i.e. within analysed countries and due to available diagnostic variables. In Table 5 appropriate groups, for a clear distinction, are marked in colour according to the division rules presented in Table 4.

Table 5. The hierarchy of European countries due to the level of PE/VC market development based on the Hellwig synthetic index value

\begin{tabular}{cccccc}
\hline $\mathbf{2 0 1 0}$ & $\mathbf{2 0 1 1}$ & $\mathbf{2 0 1 2}$ & $\mathbf{2 0 1 3}$ & $\mathbf{2 0 1 4}$ & $\mathbf{2 0 1 5}$ \\
\hline UK & FR & UK & FR & FR & UK \\
DE & UK & FR & UK & UK & FR \\
FR & DE & NL & AT & CH & DE \\
DK & AT & DE & NL & IE & SE \\
NL & NL & DK & PT & BE & PT \\
BE & BE & BE & CH & DE & CH \\
IT & Bal & SE & BE & NL & BE \\
Bal & NO & NO & DE & LU & DK \\
SE & DK & CH & DK & AT & AT \\
ES & PT & ES & LU & Bal & ES \\
CH & ES & IE & Bal & FI & NL \\
IE & FI & LU & SE & DK & IE \\
FI & IE & IT & ES & PT & LU \\
\hline
\end{tabular}




\begin{tabular}{cccccc}
\hline LU & CH & PT & PL & NO & NO \\
NO & SE & AT & RO & SE & Bal \\
HU & LU & FI & FI & ES & FI \\
AT & RO & PL & CEE & CZ & PL \\
CEE & HU & Bal & IE & IT & HU \\
CZ & PL & UA & IT & CEE & IT \\
PT & CZ & CZ & CZ & PL & CZ \\
PL & GR & CEE & HU & RO & UA \\
GR & IT & RO & NO & BG & CEE \\
BG & CEE & HU & UA & HU & BG \\
RO & BG & BG & BG & UA & GR \\
UA & UA & GR & GR & GR & RO \\
\hline
\end{tabular}

Analysis of the PE/VC market using the taxonomic method, which is a Hellwig synthetic development measure, gives the opportunity to determine the current level of PE/VC market development by using a single numerical value and the classification of countries from those with the highest level to those with the lowest level of development. It enables and facilitates the comparison between countries. Conducting detailed analyses for individual years gives a broader picture of what constitutes a very high, high, moderate or low level of PE/VC market development in Europe. The following Figure 2 presents the division in 2015.

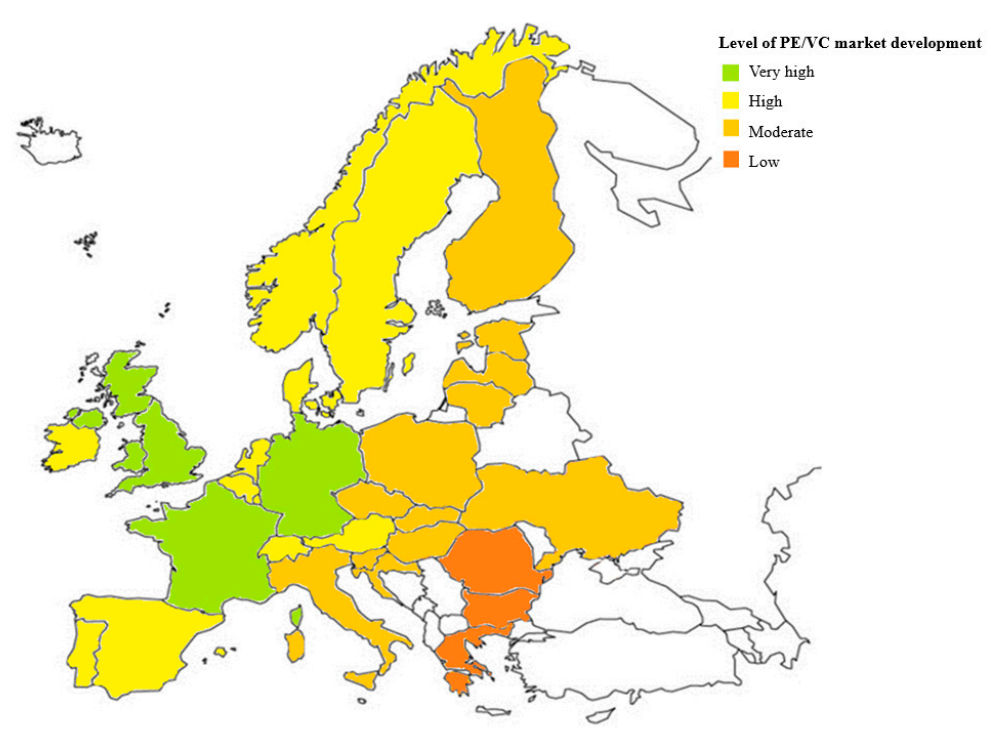

Figure 2. The map of Europe with an indication of the level of PE/VC market development in Europe based on the Hellwig synthetic index measure, in 2015

\section{Discussion}

The Hellwig method enabled creation of the ranking of countries and classify them into groups. Analysis of particular groups of similar countries, gives the opportunity to formulate general characteristics of the PE/VC market in Europe. These characteristics including the size of investments, their share in GDP, source of origin, industry structure etc., were presented in a tabular form in Table 6 below. Such an analysis, using taxonomic methods were not presented in researches yet. 
Table 6. Comparison of individual features defining the level of PE/VC market development in Europe, based on analyses for 2010-2015, in G1-G4 groups determined by the Hellwig method

\begin{tabular}{|c|c|c|c|c|}
\hline Group & G1 & G2 & G3 & G4 \\
\hline $\begin{array}{l}\text { The level of PE/VC development in } \\
\text { Europe }\end{array}$ & Very high & High & Moderate & Low \\
\hline $\begin{array}{l}\text { The range of PE/VC investment value in } \\
\text { total [in million euro] }\end{array}$ & $2.000-20.000$ & $100-6.000$ & $15-1.500$ & $1-100$ \\
\hline The range of $\mathrm{PE} / \mathrm{VC}$ share in GDP & $0,2 \%-0,7 \%$ & $0,2 \%-0,7 \%$ & $0,0 \%-0,5 \%$ & $0,0 \%-0,1 \%$ \\
\hline $\begin{array}{l}\text { The range of share of domestic PE/VC in } \\
\text { all PE/VC capital invested }\end{array}$ & $45 \%-90 \%$ & $60 \%-95 \%$ & $55 \%-100 \%$ & $90 \%-100 \%$ \\
\hline \multirow{3}{*}{$\begin{array}{l}\text { Averaged share of industries attracting } \\
\text { the most PE/VC investments* }\end{array}$} & $14 \% \operatorname{cg} \& \mathrm{r}$ & $16 \%$ ls & $15 \%$ ls & $31 \% \mathrm{c}$ \\
\hline & $14 \%$ ls & $14 \% \mathrm{cg} \& \mathrm{r}$ & $13 \% \operatorname{cg} \& r$ & $15 \% \operatorname{cg} \& \mathrm{r}$ \\
\hline & $14 \%$ b\&is & $13 \%$ b\&ip & $11 \% \mathrm{c}$ & $14 \%$ c\&ce \\
\hline $\begin{array}{l}\text { The range of the investment share of } \\
\text { high-tech in general PE/VC invested }\end{array}$ & $5 \%-25 \%$ & $5 \%-45 \%$ & $1 \%-30 \%$ & $0 \%-40 \%$ \\
\hline The PE/VC capital structure due to & $8 \%$ & $10 \%$ & $10 \%$ & $20 \%$ \\
\hline company's development phases (order: & $15 \%$ & $20 \%$ & $25 \%$ & $30 \%$ \\
\hline seed + start-up / growth / buyout) & $65 \%$ & $60 \%$ & $50 \%$ & $40 \%$ \\
\hline
\end{tabular}

* b\&ip - business \& industrial products; b\&is - business and industrial services; c - communications; c\&ce computer and consumer electronics; cg\&r - consumer goods \& retail; ls - life sciences.

The results of the analysis shows that unquestionable leaders of the European PE/VC market are: Great Britain, Germany and France. It is not surprising, as these countries constitute the core of $\mathrm{PE} / \mathrm{VC}$ investment covering over 70\% of all PE/VC investments in Europe (76\% in 2015 - total 33622917 thousand euro). What's more, according to the International Innovation Index (a global index measuring the level of innovation of a country, produced jointly by The Boston Consulting Group - BCG), these countries are in the world top 20 countries with the highest level of innovation (Dutta, Lanvin 2013). The level of economy innovativeness has a very strong impact on the pace of PE/VC market development and vice versa. The first group includes, in some years, also countries such as the Netherlands, Austria, Portugal and Switzerland. These countries were characterized by the highest level of PE/VC investments in Europe and their high share in GDP in 2010-2015. 55\% of the PE/VC funds invested in that period were foreign capitals. The industry structure was diversified - all market sectors received private equity financing, but the sectors that gained the most capital were: life sciences, consumer goods \& retail and business \& industrial services. Up to $25 \%$ of invested $\mathrm{PE} / \mathrm{VC}$ funds supported high-tech projects. Investments in the final phases of companies development dominated in that group of countries (more than half of the PE/VC resources went to companies at buyout stage), while the financing of businesses in the early stages of development was negligible. These countries presented a strong share of human resources employed in science and technology and the high number of patent applications reaching the EUP.

The second group, associating countries with a high level of PE/VC market development, is relatively diverse and consists of, among others, from: Belgium, Luxemburg, the Netherlands, Austria, Denmark, Sweden and Switzerland. In some years there were also included the Baltic countries, Portugal, Spain, and Norway. Although depending on the year of the study countries change places in the hierarchy within the group, the overall structure remains relatively stable. These countries are also included in the first 20 countries with the highest International Innovation Index. Although the structure of PE/VC market is similar to the previous group G1, most of the analysed 
factors reach slightly lower values. However, in that group more PE/VC funds support projects concerning modern technologies.

The third group includes countries where the level PE/VC market of development is assessed as sufficient/moderate. It includes mainly Poland, the Czech Republic, Italy, Spain and Finland. Also Romania and other Central and Eastern European countries (CEE) have appeared several times in this group. In the case of G3 group, the situation is not as stable as in the G1. A relatively strong displacement occurs in the rankings, depending on the year. This situation is influenced by the fact that in the case of countries from that group, investment values and other indicators are not significant, thus each positive signal from the market (small investment growth, increase in the number of patents or participation in the high-tech sector even by a unit) strongly affects the value of the synthetic indicator of a given country. Hence, countries that are on the border of clusters relatively often change their position within the group. As for the characteristics described in the above tables, the countries of this group show average values. This group is characterized by a greater interest of investors in projects in the growth phase.

The last group G4, with the lowest rating of the level PE/VC market development in Europe, consists mainly of the following countries: Bulgaria, Greece, Ukraine, Romania and Hungary. These countries (with the exception of Hungary) are at the last places of the International Innovation Index for European countries. Due to the low maturity of the PE/VC market, they were characterized by a significant share of domestic capital and increased investments in companies in the early stages of development. The level of employment in science and technology in these countries, and hence the number of patent applications in the European Patent Office, were lower here than in the other countries. In this group there was a strong focus of investors on a small number of industries/sectors in a given year.

\section{Conclusions}

Determining the level of PE/VC market development and the way it operates is extremely difficult. Moreover, economic turbulence has also had an impact on the volatility and transformation of this sector in recent years. Their impact strongly affected the PE/VC market in Europe, that only five countries out of the 25 managed to achieve the size of private equity investment at least as before the crisis in 2007. Investment value in 2015 in relations to 2007 in those countries were: Hungary (287\%), Poland (176\%), Norway (160\%), Finland (149\%), Luxemburg (118\%) (Yearbook Dataset 2015).

The conducted analysis using the Hellwig method allowed to determine the ranking of European countries in terms of the level of PE/VC market development, which reveal some significant differences in the functioning of the PE/VC market between European countries. Further detailed analysis of the designated groups of European countries allowed to determine the characteristics for countries qualified to such clusters, with a specific level of PE/VC market development. In the part of Central and Eastern Europe, both the industry structure and the share of individual types of investors in the total amount of PE/VC investments vary less than in other European countries. In Western European countries, the financing is stable and almost all sectors of the economy achieves PE/VC capital, although to different extent. The value of investments in the Central and Eastern Europe is also much lower than in other Western countries. This is most probably due to the fact that this form of financing has been operating in the Central-Eastern part of Europe since 90'. In addition, the lower level of general economic development of these countries is also reflected in the level of PE/VC market development. When it comes to financing of particular stages of enterprise development, in Central-Eastern Europe, mostly mature companies can gather financing from PE/VC funds. Newly founded enterprises, which 
are most affected by the capital gap and which are often unable to exist on the market without external support, receive less private equity funds.

The use of taxonomic methods in the PE/VC market analysis may be extremely useful in characterizing this market. The analysis of this sector from the global perspective does not exclude, and even simplify, the detailed research of this market in chosen countries, indicating specific reference points. An in-depth analysis allows the identification of weaknesses and strengths as well as opportunities and threats related to a specific stage of PE/VC market development in a given country, what gives the opportunity to determine public activities that could affect the acceleration of this market development.

By defining the level of PE/VC market development in specific groups of European countries and classifying characteristics for these groups, it is possible to compare each country to determine outliers. This allows you to verify the weaknesses and strengths of the PE/VC market in particular, chosen country. The example may be Polish market presented in Table 7.

Table 7. Assessment of the convergence level of Polish PE/VC market in relation to the designated models

\begin{tabular}{|c|c|c|c|c|}
\hline Group & G1 & G2 & G3 & G4 \\
\hline PE/VC investment value & & $\mathrm{X}$ & $X X$ & \\
\hline PE/VC share in GDP & & & $X X$ & $X X$ \\
\hline Share of domestic PE/VC investments in all PE/VC capitals & & & $X X$ & $x$ \\
\hline Structure of PE/VC capital due to sector/industry & & $x$ & $X X$ & \\
\hline Level of investment in high-tech sector & & & & $X X$ \\
\hline $\begin{array}{l}\text { Structure of } \mathrm{PE} / \mathrm{VC} \text { capital due to level of investment in } \\
\text { particular companies stage of development }\end{array}$ & & $X X$ & $X X$ & \\
\hline
\end{tabular}

The comparison allows the indication of the areas of possible application of remedial measures to limit development barriers of the Polish market. It is clearly visible that in the areas of the value of $\mathrm{PE} / \mathrm{VC}$ investment, the share of domestic capitals and the level of investment in high-tech sector, this market is more similar to countries with lover level of development. These areas might be treated as those that need specific actions (e.g. done by government), that would improve the situation and boost the PE/VC development in Poland. It is worth mentioning as well the structure of PE/VC capital due to level of investment in particular companies stage of development should also be taken into account when preparing the action plan. Although the structure in Poland is more similar to those presented by countries with higher level of development, it does not mean, that in the current situation it is convenient. Country that would like to develop the venture capital market should encourage investors to focus on young, innovative companies (e.g. in the area of high-tech), instead of investing mainly in final stages of companies development for capitalizing gains faster.

$\mathrm{PE} / \mathrm{VC}$ sector is very important from the perspective of small and medium enterprises, and for the total economy development. Better understanding of this market is thus crucial for the government investment \& legislative strategies. A separate comparing analysis, as presented for Poland, may be prepared for each country to determine the proper plan for public actions.

\section{References

Funding: “This research was funded by grant for financing research for young scientists: employees and PhD students up to 35 years old, at University of Lodz, Poland, B1711200001644.02"

Conflicts of Interest: “The authors declare no conflict of interest." 
420

421

422

423

424

425

426

427

428

429

430

431

432

433

434

435

436

437

438

439

440

441

442

443

444

445

446

447

448

449

450

451

452

453

454

455

456

457

458

459

460

461

462

463

464

465

466

467

468

469

470

471

(Bąk 2016) Bąk A. 2016. Porządkowanie liniowe obiektów metodą Hellwiga i TOPSIS - analiza porównawcza (translation: Linear ordering of objects using Hellwig and TOPSIS methods - a comparative analysis). In Taksonomia 26 Klasyfikacja i analiza danych - teoria i zastosowania, Prace Naukowe Uniwersytetu Ekonomicznego we Wrocławiu. Uniwersytet Ekonomiczny we Wrocławiu, Wroclaw, no 426, p. 23.

(Bąk 2013) Bąk A. 2013. Metody porządkowania liniowego w polskiej taksonomii - pakiet PLLOLD (translation: Linear ordering methods in Polish taxonomy - PLLOLD package). In Taksonomia 20. Klasyfikacja $i$ analiza danych - teoria $i$ zastosowania, Prace Naukowe Uniwersytetu Ekonomicznego we Wrocławiu. Uniwersytet Ekonomiczny we Wrocławiu, Wroclaw, no 278, p. 56.

(Depta 2005) Depta A. 2005. Zastosowanie metod statystycznych do oceny ryzyka na przykładzie rynków kapitałowych (translation: Application of statistical methods to risk assessment on the example of capital markets). Doctoral dissertation prepared under the scientific supervision of prof. Czesław Domański, Wydział Ekonomiczno-Socjologiczny UŁ, Lodz 2005, p. 69.

(Dutta, Lanvin 2013) Dutta S., Lanvin B. 2013. The Global Innovation Index 2013: The Local Dynamics of Innovation. Cornell University, INSEAD and WIPO, pp. 22-23.

(Grabiński 1992) Grabiński T. 1992. Metody taksonometrii (translataion: Methods of taxononometry). Akademia Ekonomiczna w Krakowie, Cracow, pp. 134-136.

(Grabiński, Wydymus, Zeliaś 1989) Grabiński T., Wydymus S., Zeliaś A. 1989. Metody taksonomii numerycznej w modelowaniu zjawisk społeczno-gospodarczych (translation: Methods of numerical taxonomy in modeling socio-economic phenomena). PWN, Warszawa, p. 9.

(Grajewska 2013) Grajewska M. 2013. Taksonomiczna analiza przestrzennego zróżnicowania poziomu rozwoju społeczno-gospodarczego w Polsce w latach 2003-2009 (translation: Taxonomic analysis of the spatial diversity of the level of socio-economic development in Poland in 2003-2009). In Finanse, Rynki Finansowe, Ubezpieczenia - Zeszyty Naukowe Uniwersytetu Szczecińskiego. Uniwersytet Szczeciński, no 786, 64/2, p. 50.

(Hellwig 1981) Hellwig Z. 1981. Wielowymiarowa analiza porównawcza i jej zastosowanie w badaniach wielocechowych obiektów gospodarczych (Translation: Multidimensional comparative analysis and its application in studies of multi-technical economic facilities). In Welfe W., Metody i modele ekonomicznomatematyczne w doskonaleniu zarzadzania gospodarka socjalistyczna. PWE, Warsaw, p. 48.

(Hellwig 1968) Hellwig Z. 1968. Zastosowanie metody taksonomicznej do typologicznego podziału krajów ze względu na poziom ich rozwoju oraz zasoby i strukturę wykwalifikowanych kadr (translation: Application of the taxonomic method to the typological division of countries due to the level of their development and the resources and structure of qualified personel). In Przeglad Statystyczny, T. 15, no 4, pp. 307-327.

(Human resources 2016) Human resources in science and technology - HRST. 2016. Eurostat, European Commission, ec.europe.eu, [online], $<$ http://ec.europa.eu/eurostat/tgm/table.do?tab=table\&init=1\&plugin=1\&language=en\&pcode=tsc00025>, 11.08.2016.

(Human resources 1995) Human resources in science and technology - HRST. 1995. Eurostat, Human resources in science and technology (HRST) as a share of the active population in the age group 25-64, Canberra Manual, OECD, Paris, 1995.

(Krakowiak-Bal 2005) Krakowiak-Bal A. 2005. Wykorzystanie wybranych miar syntetycznych do budowy miary rozwoju infrastruktury technicznej (translation: The use of selected synthetic measures to build measures for the development of technical infrastructure). In Infrastruktura i Ekologia Terenów Wiejskich. PAN Oddział w Krakowie, Cracow, No 3, p. 72.

(Nowak 1997) Nowak E. 1997. Wielowymiarowa analiza porównawcza w modelowaniu kondycji finansowej przedsiębiorstw (translation: Multidimensional comparative analysis in modeling the financial condition of enterprises). In Annales Universitatis Mariae Curie-Skłodowska, Sectio H - Oeconomia. VOL. XXXI, p. 116.

(Patent applications 2016) Patent applications to the European patent office (EPO) by priority year. 2016. Eurostat, European Commission, [online], $<$ http://ec.europa.eu/eurostat/tgm/table.do?tab=table\&init=1\&plugin=1\&language=en\&pcode=tsc00009>, 11.08.2016.

(Sectoral Classification 2016) Industry nomenclature according to the EVCA sector classification used in 20072015. 2016. Sectoral Classification, Invest Europe, investeurope.eu, pp. 1-7, [pdf] https://www.investeurope.eu/media/12926/sectoral_classification.pdf 
472

473

474

475

476

477

478

479

480

481

482

483

484

485

486
(Shraddha, Suchita, 2011) Shraddha P., Suchita G. 2011. A comparative study on distance measuringapproaches for clustering. International Journal of Research in Computer Sciencee, Volume 2, White Globe Publications, p. 29-31.

(Warzecha 2013) Warzecha K. 2013. Syntetyczna ocena dystansu Polski od krajów Unii Europejskiej na podstawie wybranych aspektów ochrony środowiska (translation: Synthetic assessment of Poland's distance from European Union countries based on selected aspects of environmental protection). In Zarządzanie i Finanse. Wydział Zarządzania Uniwersytetu Gdańskiego, vol 11, no 4/4., p. 328.

(Yearbook Dataset 2015) 2007-2015 Dataset Europe Country Tables. 2016. Invest Europe, [xls], $<$ https://www.investeurope.eu/media/477249/2007-2015-dataset-europe-country-tables-publicversion_final.xlsx>.

(Yearbook 2016) Yearbook 2016 - Europe and country overview tables. 2017. Invest Europe, [xls] $<$ https://www.investeurope.eu/media/652475/yearbook-2016-europe-and-country-overview-tablesmember-version-20170510.xlsx>.

(Zimny 2013) Zimny A. 2013. Decyzje na rynkach Venture Capital/ Private Equity (translation: Decisions on the Venture Capital/Private Equity markets). Wydawnictwo Uniwersytetu Łódzkiego, Lodz, pp. 119-121. 